\section{ÉLETTARTAM-KOCKÁZAT CSEHORSZÁGBAN ÉS MAGYARORSZÁGON}

Gogola Ján (Academic FES, University of Pardubice, Institute of Mathematics and Quantitative Methods), jan.gogola@upce.cz, Vékás Péter (egyetemi adjunktus, Budapest Corvinus Egyetem, Operációkutatás

és Aktuáriustudományok Tanszék), peter.vekas@uni-corvinus.hu

\section{ÖSSZEFOGLALÓ}

Az élettartam-kockázat a vártnál hosszabb élettartamokból fakadó pénzügyi kockázat mely a nyugdíjrendszereket és az életjáradékokat értékesítő biztosítókat érinti legsúlyosabban. Ezért a jövőbeli halandósági ráták előrejelzése ezen szereplők számára alapvető jelentőségű. Elemzésünkben a magasabb, 65-95 éves életkorokra fókuszálunk, mivel a nyugdíjjal kapcsolatos alkalmazásokat tartjuk szem elött, amelyekben a hosszú távú pénzáramok bizonytalansága elsősorban az ezen életkorokhoz tartozó halandósági ráták alakulásából fakad.

A Human Mortality Database (HMD) adatbázisból Csehország és Magyarország halálozási és kitettségi adatsorait használjuk fel, és megmutatjuk, hogy a jelenlegi tendenciák folytatása esetén a szolgáltatással meghatározott nyugdíjtervek kötelezettségeinek értéke Magyarországon 3,77, Csehországban pedig 4,66 százalékkal fog emelkedni, amennyiben a klasszikus periódus (statikus) halandósági tábla helyett kohorsz (dinamikus) táblát használunk.

\section{SUMMARY}

Longevity risk, the risk that people will live longer than expected, weighs heavily on those who run pension schemes and on insurers that provide annuities. Hence the prediction of future mortality rates is an issue of fundamental importance for the insurance and pensions industry.

Our analysis focuses on mortality at higher ages (65-95), given our interest in pension-related applications where the risk associated with longer-term cash flow is primarily linked to uncertainty in future rates of mortality.

We use data on deaths and exposures for Czech Republic and Hungary from the Human Mortality Database (HMD). We have shown that if the current rate of increase continues, it will increase the present value of pension liabilities in defined-benefit schemes by about $3.77 \%$ for Hungary and $4.66 \%$ for the Czech Republic, if we use a cohort life (dynamic approach) table instead of a period life table (static approach).
Kulcsszavak: élettartam-kockázat, sztochasztikus halandóság, halandósági tábla, Lee-Carter modell, életjáradék

Keywords: longevity risk, stochastic mortality, life table, Lee-Carter model, annuity

JEL: C53, G22, J11, J32

DOI: $10.18530 /$ BK.2020.3-4.14

http://dx.doi.org/10.18530/BK.2020.3-4.14

\section{Bevezetés}

Benjamin Franklin híres mondása: „Ebben a világban semmi nem mondható biztosnak, kivéve a halált és az adókat." A halál biztos, de az időzítése annál kevésbé. A fejlett országok lakosságának halálozása gyorsan javult az elmúlt száz évben, és ennek jelentős pénzügyi következményei vannak a biztosítási szektorban, mivel számos biztosítási ágazat - és ezek közül is leginkább az egészség-, élet- és nyugdíjbiztosítás - profitabilitása érzékeny a jövőbeli halálozási tendenciák alakulására.

A halálozás jövőbeli alakulásával kapcsolatos az úgynevezett élettartam-kockázat (angolul „longevity risk”), a hosszú élettartam kockázata, amely abból fakad, hogy az emberek a vártnál hosszabb ideig élnek. Ez súlyosan érinti a nyugdíjrendszereket és a járadékszolgáltatókat, mivel a folyó finanszírozású állami nyugdíjrendszerek járulékbevételei vagy az ellátások kifizetésére létrehozott (nyugdíj-, özvegyi, árva, rokkantsági stb.) tartalékok nem elegendők, ha a valósnál alacsonyabb túlélési arányt feltételező halandósági táblára épülnek. Az élettartam-kockázat központi szerepet játszik, mivel csak a halálozás jövőbeli alakulására vonatkozó körültekintő feltevések teszik lehetővé a nyugdíjrendszerek és biztosítótársaságok számára, hogy teljesítsék jövőbeli kötelezettségeiket. Az élettartam-kockázat a biztosítási kockázati modul részmodulja a Szolvencia II keretrendszerben.

Az 1. ábra azt bizonyítja, hogy a V4 országokbeli élettartam átlagos hossza az elmúlt évtizedek során jelentősen növekedett. A „Longevity swaps: Live long and prosper” (The Economist, 2010) c. cikkből idézünk: „A 65 éves korban várható élettartam minden további egy év növekedése esetén a brit szolgáltatással meghatározott nyugdíjrendszer kötelezettségeinek jelenértéke 3\%-kal, vagyis 30 milliárd fonttal (48 milliárd dollár) emelkedik."

Ez a cikk arra ösztönzött bennünket, hogy megbecsüljük, milyen hatással van a várható élettartam a járadékok jelenértékére a mi célországainkban: Magyarországon és Csehországban.

A legnépszerűbb és legszélesebb körben használt halandóság-előrejelző modell a jól ismert Lee-Carter (1992) modell. A legtöbb sztochasztikus halálozási modell hasonló 
módon épül fel: a történelmi adatokhoz illeszkednek, és egy vagy több, időben változó paramétert azonosítanak.

Ezeknek a paramétereknek a jövőre történő extrapolálásával becslést kaphatunk a jövőbeli halálozási valószínűségekről és ennek következtében más demográfiai menynyiségekről, például a várható élettartamról.

A modellt és kiterjesztéseit csehországi adatokon Gogola (2014a, 2014b és 2015), magyarországi adatokon Baran és szerzőtársai (2007), Arató és szerzőtársai (2009), Májer és Kovács (2011), Bajkó és szerzőtársai (2015) és Vékás (2017, 2018 és 2019), valamint nemzetközi adatokon Jindrová és Slavíček (2012) alkalmazzák. Májer és Kovács (2011) az 1970- 2006 közötti évek adataira illesztett Lee-Carter modell alapján megállapítják, hogy a 65 évesen induló előleges életjáradék egyszeri nettó diját 4,51 százalékkal becsüli alá a dinamikát figyelmen kívül hagyó statikus számítás. Vékás (2017) számítása szerint az 1975-2014 bázis időszak alapján ugyanerre a különbségre az általánositott korcsoport-időszak-kohorsz (GAPC, Villegas és szerzőtársai, 2016) modellcsalád és a Cairns-Blake-Dowd (2006) modell alapján 6,43 százalék adódik.

A Lee-Carter modell számos kiterjesztését mutatják be Booth és szerzőtársai (2005), valamint Villegas és szerzőtársai (2016). Pacáková és Iindrová (2014) az Európai Unió adatain vizsgálják, hogy mely egészségügyi tényezők befolyásolják a 65 évesen várható élettartam növekedését. A halandóságjavulás trendjében az elmúlt években tapasztalt fordulatról ír Horváth (2019). A halandósági görbék klaszterezésével új megközelítésben foglalkozik Ágoston (2020).

Cikkünk fö célja, hogy a Lee-Carter modellt alkalmazzuk az úgynevezett kohorsz halandósági táblák elkészitésére, és felhasználjuk az eredményeket egy 30 éves tartamú életjáradék dijának kiszámításához egy 65 éves korú személyre 2018-ban, majd ezt összevetve a statikus tábla alapján számított klasszikus díjjal megkíséreljük számszerűsíteni az élettartam-kockázat nagyságát Csehországban és Magyarországon. A 30 év tartamú életjáradék díjának kiszámításából következik, hogy csak a 65 és 95 közötti életkorokra vonatkozik az elemzésünk. Ennek fö oka, hogy az adatok megbízhatatlanok 95 éves kor felett: alacsonyak a megfigyelésszámok, és az elhalálozási korokról gyakran téves adatokat jelentenek ilyen magas életkorokban (Spoorenberg, 2007), így megbízhatatlan halálozási arányokat kapnánk. Másrészről a népesség igen csekély hányada éri el a 95 éves kort, és az ezután következő pénzáramokat legalább 30 évnyi technikai kamattal is diszkontálni szükséges, így ez az egyszerüsítés az életjáradék diján lényegében nem változtat.
1. ábra: A születéskor várható élettartam a V4 országokban

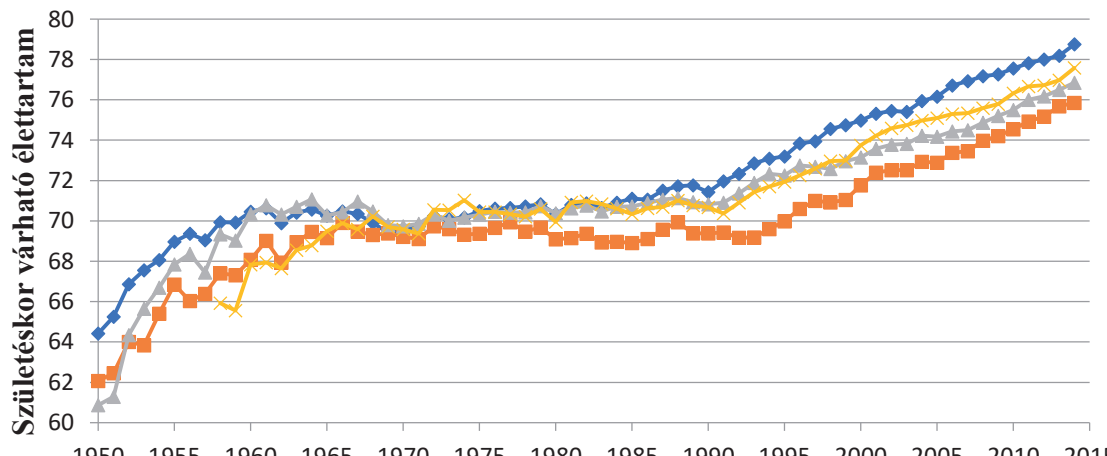

$\rightarrow$ Czech Republic $\rightarrow$-Hungary $\rightarrow$ Slovakia $\rightarrow$ Poland

Forrás: Human Mortality Database (HMD, www.mortality.org)

\section{Módszertan}

Magyarország és Csehország 1950 és 2014 közötti uniszex¹ néphalandósági és kitettségi adatait használjuk a Human Mortality Database (HMD) adatbázisból (www.mortality.org). Feltételezzük, hogy minden egyes $x \in\left\{1,2, \ldots, n_{a}\right\}$ korcsoportban és $t \in\left\{1,2, \ldots, n_{y}\right\}$ időszakban ismert a bekövetkezett halálesetek $d_{x, t}$ száma valamint az $e_{x, t}$ központi kitettség ${ }^{2}$ értéke. Brouhns és szerzőtársai (2002) nyomán feltételezzük, hogy a halálesetek számai Poisson-eloszlású valószínüségi változók:

$$
d_{x, t} \sim \operatorname{Poisson}\left(e_{x, t} \cdot m_{x, t}\right)
$$

A Lee-Carter (1992) modell Brouhns és szerzőtársai (2002) által ismertetett változatában ${ }^{3}$ az $m_{x, t}=\frac{d_{x, t}}{e_{x, t}}$ központi halandósági ráták az

$$
\ln m_{x, t}=\alpha_{x}+\beta_{x} \cdot \kappa_{t}
$$

egyenlettel írhatók le, ahol a (2) egyenlet paramétereire az egyértelműség kedveért érvényesnek tekintjük a következő paramétermegkötéseket:

$$
\begin{aligned}
& \sum_{x=1}^{n_{a}} \beta_{x}=1, \\
& \sum_{t=1}^{n_{y}} \kappa_{t}=0 .
\end{aligned}
$$

A (2) egyenlet paraméterei maximum likelihood elven becsülhetők, a Poisson log-likelihood függvény numerikus maximalizálásával. Az $\alpha_{x}$ paraméterek a logaritmikus mortalitáséletkoronkénti 
átlagos szintjét, a $\beta_{x}$ együtthatók a halandóság életkoronkénti csökkenési ütemét, a mortalitási indexnek is nevezett $\kappa_{t}$ idősor értékei pedig a néphalandóság általános alakulását írják le.

A gyakorlatban a modell paramétereinek becslése általában csak az első lépés, a módszer fó célja azonban a halálozás elörejelzése. A $\kappa_{t}$ idősor autoregresszív integrált mozgóátlagolású (ARIMA) folyamatokkal jelezhető elöre, de a való életben többnyire az eltolásos véletlen bolyongás modelljét használják. Ezt a gyakorlatot cikkünkben mi is követjük.

Az eltolásos véletlen bolyongás modellje alapján a mortalitási index időbeli alakulása a következőképpen írható le:

$$
\kappa_{t}=\kappa_{t-1}+\theta+\varepsilon_{t-1}
$$

ahol a $\theta \in R$ trendparaméter az eltolás mértéke, $\boldsymbol{\varepsilon}_{t-1}$ pedig a folyamat véletlen hibatagjait jelöli, melyek független, 0 várható értékü, azonos $\sigma_{\varepsilon}^{2}>0$ varianciájú, normális eloszlású valószínüségi változók, $\varepsilon_{t} \sim \mathcal{N}\left(0 ; \sigma_{\varepsilon}^{2}\right)$.

A $\theta$ trendparaméter és a variancia becslései a maximum likelihood módszer alapján: ${ }^{4}$

$$
\begin{aligned}
& \theta=\frac{1}{n_{y}-1} \sum_{t=2}^{n_{y}}\left(\kappa_{t}-\kappa_{t-1}\right)=\frac{\kappa_{n_{y}}-\kappa_{1}}{n_{y}-1}, \\
& \sigma_{\varepsilon}^{2}=\frac{1}{n_{y}-1} \sum_{t=2}^{n_{y}}\left(\kappa_{t}-\kappa_{t-1}-\theta\right)^{2} .
\end{aligned}
$$

A mortalitási index jövőbeli értéke a $t+h$ időszakban a

$$
\kappa_{t+h}=\kappa_{t}+h \cdot \theta+\sum_{s=0}^{h-1} \varepsilon_{t+s}
$$

alakban írható fel, amely ismert $\kappa_{t}$ esetén normális eloszlású: $\kappa_{t} \sim \mathcal{N}\left(\kappa_{t}+h \cdot \theta ; \sigma_{\varepsilon}^{2} \cdot h\right)$.

Ennélfogva jövőbeli értékének legjobb pontbecslése a $t+h$ idöpontban $\kappa_{t}+h \cdot \theta$,

és 95\%-os megbízhatósági intervalluma

$$
\left(\kappa_{t}+h \cdot \theta-1,96 \cdot \sigma_{\varepsilon} \cdot \sqrt{ } h ; \kappa_{t}+h \cdot \theta+1,96 \cdot \sigma_{\varepsilon} \cdot \sqrt{ } h\right) .
$$

A mortalitási index elörejelzett értékét a (2) egyenletbe helyettesítve kapható meg a logaritmikus halandósági ráták előrejelzése a $t+h$ időszakban:

$$
\ln m_{x, t+h}=\alpha_{x}+\beta_{x} \cdot\left(\kappa_{t}+h \cdot \theta\right) \text {. }
$$

Ezek ismeretében a $q_{x, t+h}$ koréves halálozási valószínűségek becslései a

$$
q_{x, t+h}=\frac{m_{x, t+h}}{1+0,5 m_{x, t+h}}
$$

közelítő összefüggés alapján nyerhetők.
A koréves halálozási valószínűségek alapján kiszámítható az x éves korú biztosított azonnal induló, 30 évig tartó $(n=30)$, évi egy forint összegü életjáradékának egyszeri nettó díjképlete az aktuáriusi ekvivalenciaelv alapján, a klasszikus statikus és halandóság dinamikáját figyelembe vevő dinamikus (kohorsz) szemléletben:

1. Statikus becslés

utólagos járadék $\quad a_{x: \bar{n} \mid}=\sum_{t=1}^{n} v^{t} \cdot{ }_{t} p_{x}=\sum_{t=1}^{n} v^{t} \cdot \prod_{j=1}^{t}\left(1-q_{x+j}\right)$

előleges járadék $\quad \ddot{a}_{x: \bar{n} \mid}=\sum_{t=0}^{n-1} v^{t} \cdot{ }_{t} p_{x}=\sum_{t=0}^{n-1} v^{t} \cdot \prod_{j=0}^{t-1}\left(1-q_{x+j}\right)$

$v$ a technikai kamatláb alapján számított éves diszkonttényező

2. Dinamikus (kohorszszemléletű) becslés

utólagos járadék

$$
a_{x: \bar{n} \mid}=\sum_{t=1}^{n} v^{t} \cdot \prod_{j=1}^{t}\left(1-q_{x+j, T+j}\right)
$$

előleges járadék

$$
\ddot{a}_{x: \bar{n} \mid}=\sum_{t=0}^{n-1} v^{t} \cdot \prod_{j=0}^{t-1}\left(1-q_{x+j, T+j}\right)
$$

\section{Modellezés}

A nyugdíjas korú egyének halandósági rátáinak előrejelzése érdekében a Human Mortality Database (HMD) adatbázisból Csehország és Magyarország teljes népességének 1950-2017 naptári évekre és 65-95 korévekre vonatkozó, naptári és korévek szerint bontott halálozási és kitettségi adatait használtuk fel.

A számításokat az R statisztikai programozási nyelv (R Development Core Team, 2005) és a StMoMo sztochasztikus halandóság-elörejelző kiegészítő csomag (Villegas és szerzőtársai, 2016) segítségével végeztük el. 
2. ábra: A Lee-Carter modell becsült paraméterei Magyarország (felül) és Csehország (alul) teljes népességére alpha_x

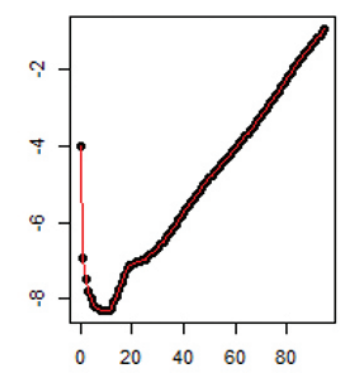

Age

alpha_x

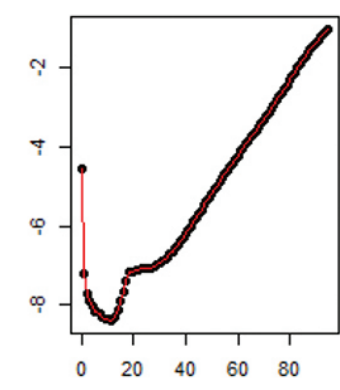

Age beta_ $x$

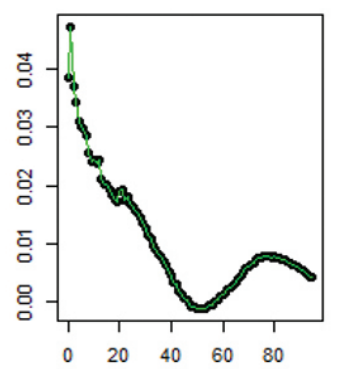

Age

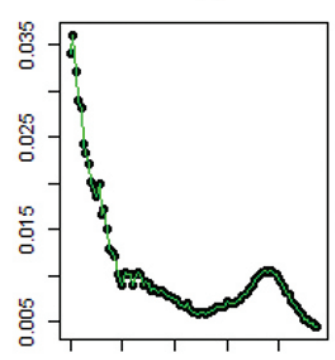

kappa_t
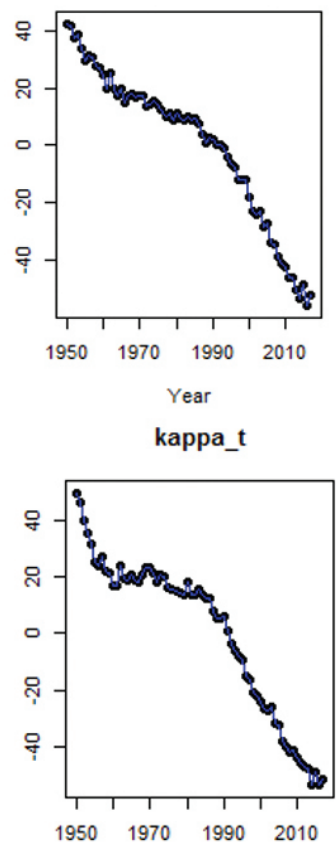

Year
Forrás: saját szerkesztés

A 2. ábra alapján a logaritmikus halálozás életkor szerinti átlagos mintázatai a két országban nagyon hasonlók: az $\alpha_{x}$ paraméterek mindkét diagramján látszik a csecsemőkori kiugrás, ezt követően a körülbelül 10 éves korig tartó csökkenés, a 20 éves kor körüli baleseti púp, végül a görbék nagyjából 30 éves kor után egyenessé válnak, vagyis ezután a halandóság az életkorral exponenciálisan nő. A halandóságcsökkenés életkoronkénti ütemét leíró $\beta_{x}$ paraméterek mintázatai között szintén nincsenek jelentős különbségek: mindkét országban csecsemőkorban a legmarkánsabb a múltbéli javulás, a csökkenési ütem ezután nagyjából 45 éves korig folyamatosan mérséklődik, majd körülbelül 75 éves korig nő, és utána újra folyamatosan csökken az életkor függvényében. Az egyetlen jelentősebb különbség, hogy 20-40 éves kor között Magyarországon érezhetően jelentősebb volt a halandóság csökkenése, mint Csehországban. A mortalitási indexek ábrái is meglepően hasonlók: 1950-1960 között gyors csökkenés, majd 1960-1990 között stagnálás és 1990 után ismét gyors javulás jellemezte mindkét ország néphalálozási mutatóit.
3. ábra: A $\kappa_{t}$ mortalitási index becsült alakulása 1950-től 2017-ig és előrejelzése 2060-ig Magyarország (felül) és Csehország (alul) teljes népességére
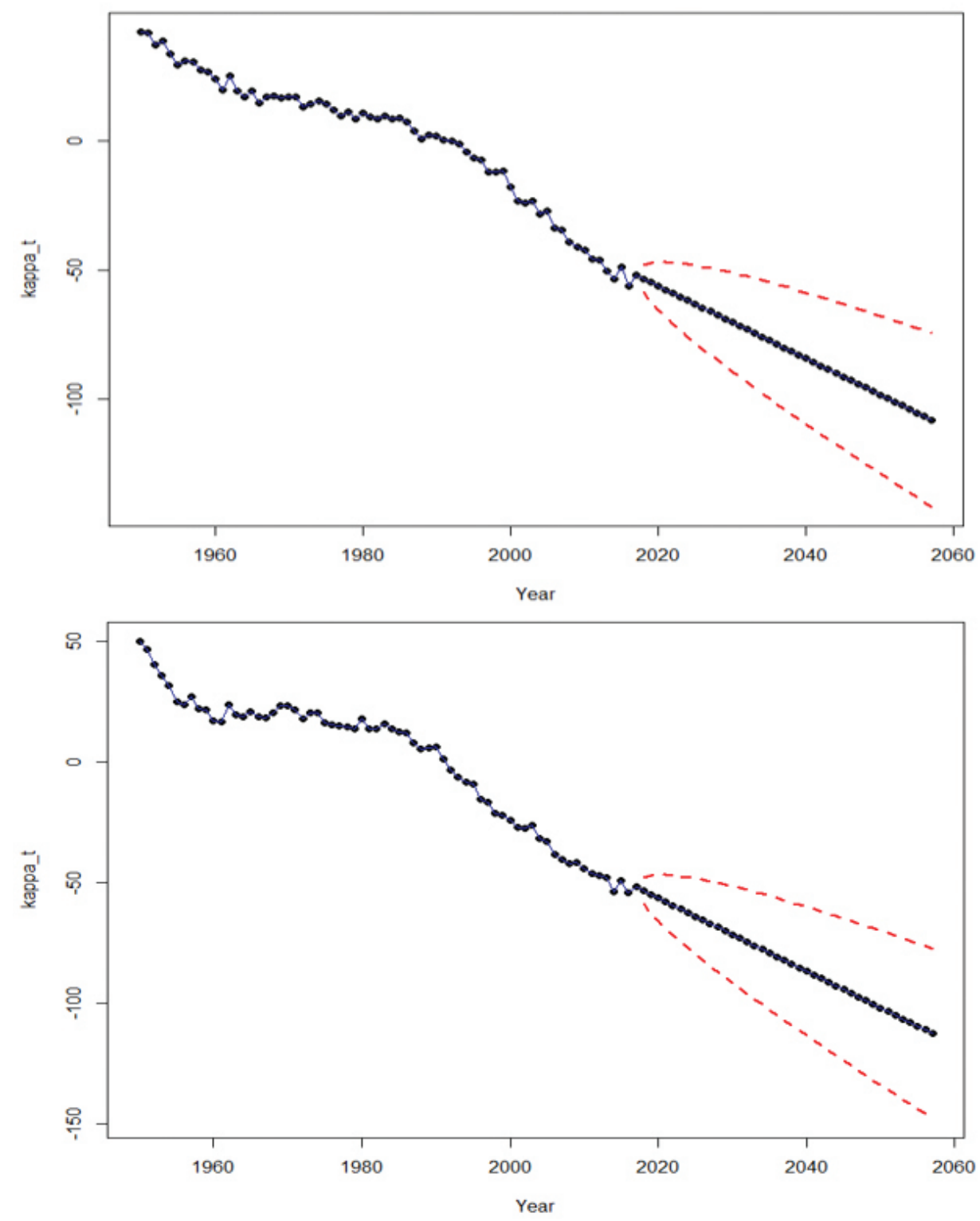

Forrás: saját szerkesztés 
1. táblázat: a $\kappa_{t}$ mortalitási index eltolásos véletlen bolyongási modelljeinek becsült paraméterei Magyarország és Csehország teljes népességére

\begin{tabular}{|l|c|c|}
\hline & $\theta$ & $\sigma_{\varepsilon}^{2}$ \\
\hline Magyarország & $-1,4057$ & 7,3438 \\
\hline Csehország & $-1,7860$ & 8,8226 \\
\hline
\end{tabular}

Forrás: saját szerkesztés

A 3. ábra és az 1. táblázat alapján mindkét országban hosszú távon átlagosan a néphalandóság gyors csökkenése volt tapasztalható az elmúlt évtizedekben, bár ez időben egyáltalán nem volt egyenletes (föleg a rendszerváltozás után tapasztalhattunk gyors csökkenést, míg ezzel szemben a 2. és 3. ábrák alapján 1960-1990 között Magyarországon semmilyen, Csehországban pedig csekély növekedés történt a várható élettartamban). A Lee-Carter modell - extrapoláló jellegéből adódóan - ugyanilyen ütemű javulást vár a jövőben is.

Jóllehet a hosszú becslési időszak egybemossa az eltérő javulási ütemű történelmi periódusokat, ugyanakkor túl rövid, 1990 körül kezdődő bázisidőszak esetén megbízhatatlanok lennének az elörejelzések: varianciájuk jelentésen nőne. Ezenkívül könnyen túlontúl optimista elörejelzéseket kapnánk, amit a halandóságjavulás mostanában számos országban megfigyelt trendfordulója is igazol. (Horváth, 2019)

A 4. ábra szerint ez várhatóan mindkét országban a $q_{x}$ görbe folyamatos lefelé tolódását fogja eredményezni. A 2. táblázat alapján azonban Csehországban a csökkenés üteme (és bizonytalansága is) valamivel gyorsabb volt és lesz is, mint Magyarországon.

4. ábra: A 2017-ben megfigyelt és a 2032-re és 2047-re elörejelzett $q_{x}$ koréves halálozási valószínűségek Magyarország (első ábra) és Csehország (második ábra) teljes népességére

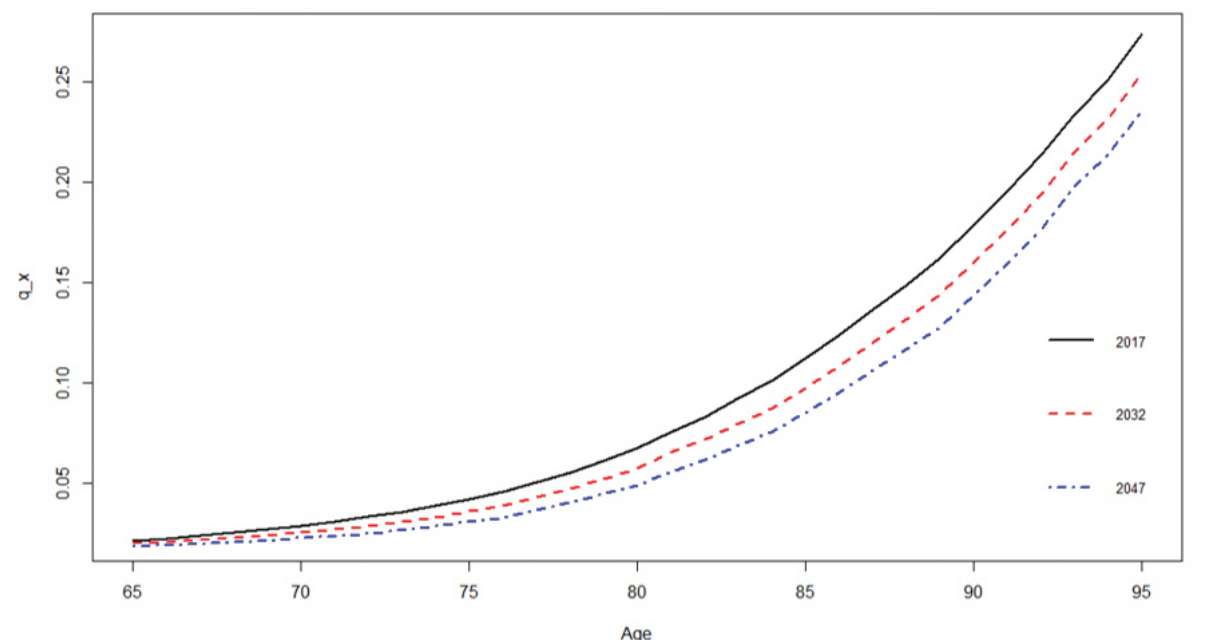

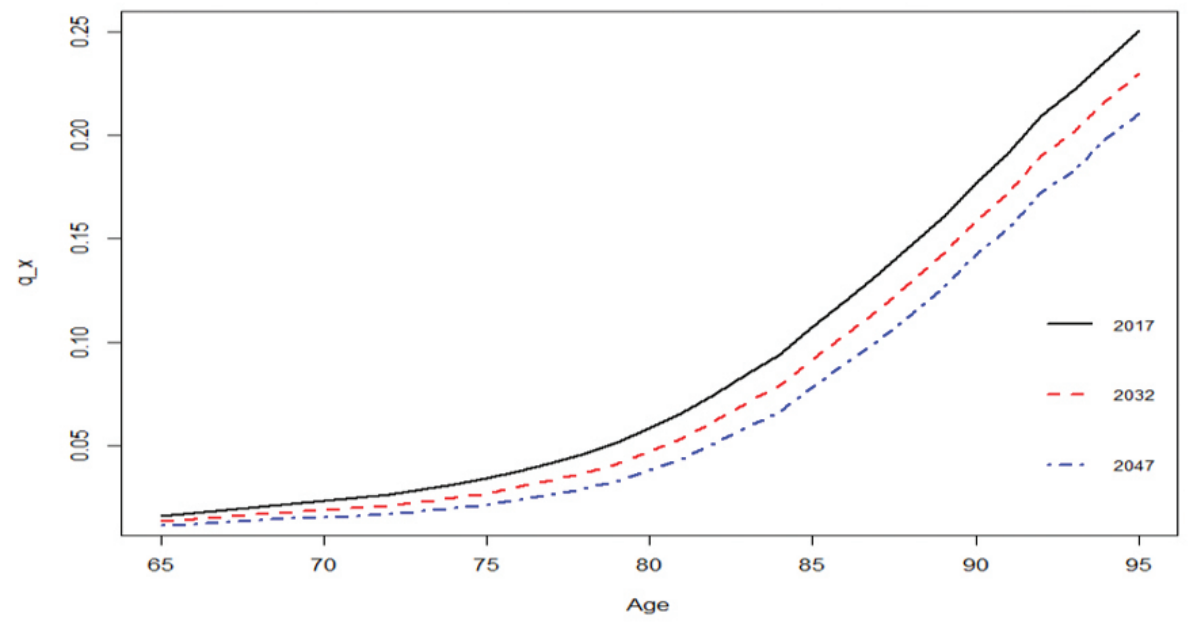

Forrás: saját szerkesztés

A legutóbbi évek fel nem használt, újabb adatai lehetőséget nyújtanak a visszatesztelésre: Csehországban a teljes elörejelzési periódus használatával kapott óvatos előrejelzés alapján 2014-2018 között 0,48 évvel nőtt volna a születéskor várható élettartam, míg a HMD alapján valójában 0,42 évvel nőtt, Magyarországon pedig a modell alapján 2014-2017 között a várható növekedés 0,27 év volt, míg valójában a HMD alapján 0,34 évnyi növekedést figyelhettünk meg. Az eltérések a legutolsó ismert adatok és elörejelzéseik között mindkét országban igen csekélyek: Csehországban csak 0,06, Magyarországon pedig csupán 0,07 évet tesznek ki. Ezen eredmények alapján az előrejelzéseink utólag meglepően megbízhatónak bizonyultak.

2. táblázat: Periódus (statikus) és kohorsz (dinamikus) halandósági táblázatok koréves halálozási valószínủségei Magyarország teljes népességére

\begin{tabular}{|c|c|c|c|c|c|c|c|}
\hline$q_{x, t}$ & 2017 & 2018 & 2019 & 2020 & 2021 & 2022 & 2023 \\
\hline 65 & 0,021239 & 0,021137 & 0,021035 & 0,020934 & 0,020833 & 0,020733 & 0,020633 \\
\hline 66 & 0,022326 & 0,022199 & 0,022073 & 0,021948 & 0,021823 & 0,0217 & 0,021576 \\
\hline 67 & 0,023628 & 0,023478 & 0,023329 & 0,023181 & 0,023033 & 0,022887 & 0,022742 \\
\hline 68 & 0,025100 & 0,024922 & 0,024745 & 0,02457 & 0,024396 & 0,024223 & 0,024051 \\
\hline 69 & 0,026668 & 0,02646 & 0,026253 & 0,026048 & 0,025845 & 0,025643 & 0,025443 \\
\hline 70 & 0,028681 & 0,028445 & 0,02821 & 0,027978 & 0,027747 & 0,027519 & 0,027292 \\
\hline 71 & 0,030694 & 0,030419 & 0,030147 & 0,029877 & 0,029609 & 0,029344 & 0,029081 \\
\hline - & - & $\cdot$ & & $\bullet$ & & . & \\
\hline
\end{tabular}

Forrás: saját szerkesztés 
A 2. táblázat a periódus (statikus) és kohorsz (dinamikus) halandósági táblák egy részletét mutatja Magyarország teljes népességére: az utolsó ismert, 2017. év oszlopából készíthető el a statikus tábla, illetve a színezett átlóból a 2017-ben 65 évesek kohorsz (dinamikus) halandósági táblája, amelyekből a (12)-(15) képletek alapján előállítható a 2017-ben 65 éves korúak előleges és utólagos, évi $1 \mathrm{Ft}$ összegü életjáradékának nettó díja. (4. táblázat)

3. táblázat: Periódus (statikus) és kohorsz (dinamikus) halandósági táblázatok koréves halálozási valószínüségei Csehország teljes népességére

\begin{tabular}{lrrrrrrr}
\hline$q_{x, t}$ & \multicolumn{1}{c}{2017} & 2018 & \multicolumn{1}{c}{2019} & \multicolumn{1}{c}{2020} & 2021 & \multicolumn{1}{l}{2022} & 2023 \\
\hline 65 & 0,01901 & 0,018743 & 0,018479 & 0,01822 & 0,017963 & 0,017711 & 0,017462 \\
\hline 66 & 0,020608 & 0,020312 & 0,02002 & 0,019733 & 0,019449 & 0,01917 & 0,018894 \\
\hline 67 & 0,022297 & 0,021968 & 0,021644 & 0,021324 & 0,02101 & 0,020699 & 0,020393 \\
\hline 68 & 0,023966 & 0,023601 & 0,023242 & 0,022888 & 0,02254 & 0,022197 & 0,021859 \\
\hline 69 & 0,026093 & 0,025688 & 0,02529 & 0,024897 & 0,02451 & 0,024129 & 0,023754 \\
\hline 70 & 0,02897 & 0,028527 & 0,028091 & 0,027661 & 0,027238 & 0,026821 & 0,026411 \\
\hline 71 & 0,031538 & 0,031049 & 0,030568 & 0,030094 & 0,029627 & 0,029168 & 0,028716 \\
\hline. &. &. & - & - &. &. &. \\
\hline
\end{tabular}

Forrás: saját szerkesztés

A 3. táblázat alapján 1,5\%-os technikai kamatláb esetén statikus szemléletben mind az előleges, mind az utólagos életjáradék nettó díja több mint 1 Ft-tal magasabb Csehországban, mint Magyarországon. Dinamikus szemléletben a különbség Csehország javára még szembetűnőbb. A statikus értékek a 95\%-os dinamikus konfidenciaintervallumok alsó határaira esnek, az országok konfidenciaintervallumai pedig nagyjából összeérnek egymással.

4. táblázat: A járadékok nettó díjai a teljes népességre $(x=65, n=30, i=0,015)$

\begin{tabular}{|c|c|c|c|c|}
\cline { 2 - 5 } \multicolumn{1}{c|}{} & \multicolumn{2}{c|}{ Magyarország } & \multicolumn{2}{c|}{ Csehország } \\
\cline { 2 - 5 } \multicolumn{1}{c|}{} & $a_{x: \bar{n} \mid}$ & $\ddot{a}_{x: \bar{n} \mid}$ & $a_{x: \bar{n} \mid}$ & $\ddot{a}_{x: \bar{n} \mid}$ \\
\hline Statikus halandóság & 13,69 & 14,66 & 14,83 & 15,79 \\
\hline Dinamikus halandóság & 14,26 & 15,21 & 15,59 & 16,52 \\
\hline $\begin{array}{c}\text { Dinamikus halandóság } \\
\text { (95\% konf.int.) }\end{array}$ & $13,66-14,87$ & $14,62-15,79$ & $14,83-15,59$ & $15,84-17,18$ \\
\hline Százalékos eltérés & $4,18 \%$ & $3,77 \%$ & $5,13 \%$ & $4,66 \%$ \\
\hline
\end{tabular}

Forrás: saját szerkesztés
Magyarországon a statikus szemléletü kalkuláció nagyjából 4\%-kal, míg Csehországban körülbelül 5\%-kal becsüli alá a dinamikus szemléletű, a halandóság időbeli változását is figyelembe vevő díjakat. A Májer és Kovács (2011), illetve Vékás (2017) által bemutatott 4,5\%-os és 6,43\%-os eltérésekhez hasonlóan ezek a különbségek a gyakorlatban rendkívül jelentősek: a naiv statikus díjszámítás a tartam folyamán számottevő, folyamatosan növekvő tartalékhiányhoz és veszteséghez vezet, így elengedhetetlen a halandóság-előrejelző eljárások használata.

\section{4. Összegzés}

Elemzésünkben megállapítottuk, hogy Magyarország és Csehország rendkívül hasonlók egymáshoz mind a halandóság életkoronkénti szintjei és csökkenési ütemei, mind annak múltbeli alakulása és történelmi szakaszai szempontjából. Két apróbb különbség, hogy Csehországban az elmúlt hét évtizedben összességében gyorsabb volt a javulás, nagyobb kilengések mellett, míg Magyarországon jelentősebb volt a 20-40 éves korosztályok halandóságcsökkenési üteme.

Csehországban lényegesen magasabb a 65 évesen várható élettartam és az élethosszig tartó járadék egyszeri nettó díja, mint Magyarországon, de a különbség 5\%-os szignifikanciaszinten csak épphogy szignifikáns. A dinamikus szemléletű díjak Magyarországon nagyjából 4\%-kal, míg Csehországban körülbelül 5\%-kal, mindkét országban egyaránt jelentősen magasabbak a naiv, statikus szemléletű megfelelőiknél, így országaink nyugdíj- és járadékbiztosítási aktuáriusi gyakorlatában elengedhetetlen a halandóság-előrejelző módszerek használata.

\section{Köszönetnyilvánítás}

Vékás Péter kutatásait az Európai Unió, Magyarország és az Európai Szociális Alap társfinanszírozása által biztosított forrásból az EFOP-3.6.2-16-2017-00017 azonosítójú „Fenntartható, intelligens és befogadó regionális és városi modellek” című projekt támogatta.

\section{HIVATKOZÁSOK}

'A nemenkénti vagy más kockázati csoportonkénti elemzés itt nem célunk, és az Európai Unió erre vonatkozó irányelve értelmében is tilos a járadékbiztositások dijkalkulációjában a nemek szerinti megkülönböztetés. ${ }^{2} \mathrm{Az}$ e ext központi kitettség a t naptári évben x éves egyének által megélt évek száma, vagy - ekvivalens értelmezésben átlagos létszáma.

"Brouhns és szerzőtársai (2002) modellváltozata a Lee-Carter (1992) modelltől annyiban tér el, hogy a halálesetek számának Poisson-eloszlasat feltetelezi, és a paramétereket a maximum likelihood eljárás segítségével becsül.

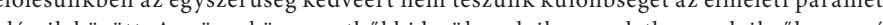

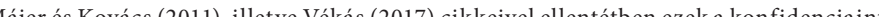
a paraméterbizonytalanságot. Ugyanakkor ez a szempont a cikk végkövetkeztetései szempontjából kevésbé lényeges. 


\section{IRODALOMJEGYZÉK}

Agoston, K. Cs. (2020): Halandósági mintázatok feltárása Heligman-Pollard halandósági függvények segítségével. Biztositás és

Kocḱázat 1-2: pp. 34-51.
https://doi.org/10.1830/bk.2020.1-2.34 letölttve 2020.06.07-én

Simulating Mortality Tables. Mathematical and Computer ps://doiorg/10.1016/jmcm 2008.01.012 letöltve 2020.06.07-én

Bajkó, A. - Maknics, A. - Tóth, K. - Vékás, P. (2015): A magyar nyugdijrendszer fenntarthatóságáról. Közgazdasági Szemle, 62(12):

pp. 1229-1257.
https://doi.org/10.18414//ksz.2015.12.1229 letöltve 2020.06.07-én

Baran, S. - Gáll, J. - Ispány, M. - Pap, G. (2007). Forecasting Hungarian mortality rates using the Lee-Carter method. Acta https://doi.org/10.1556/2oecon.57.2007.1.3 letöltve 2020.06.07-én

Booth, H. - Tickle, L. - Smith, L. (2005): Evaluation of the variants of the Lee-Carter method of forecasting mortality: a multicountry comparison. New Zealand Population Review, 31, pp. 13-34.

Brouhns, N. - Denuit, M. - Vermunt, J.K. (2002): A Poisson logbilinear regression approach to the construction of projected lifetables. Insurance: Mathematics and Economics, 31: pp. 373-393.

Cairns, A. J. G. - Blake, D. - Dowd, K. (2006): A Two-Factor Model for Stochastic Mortality with Parameter Uncertainty: Theory and Calibration. Journal of Risk and Insurance, 73(4): pp. 687-718.

https://doi.org/10.1111/j.1539-6975.2006.00195.x letölttve 2020.06.07-én.

don, England, Feb 4th 2010, ISSN 0013-0613.

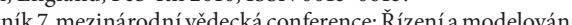
finančnich rizik, VŠB-TU Ostrava, pp. 209-2017. ciences and Finance, pp. 113-116, Springer.

https://doi.org/10.1007/978-3-319-05014-0_26 letöltve 2020.06.07-én. Gogola, J. (2015): Comparison of selected stochastic mortality models. International Journal of Mathematical Models and Methods in Applied Sciences, Volume 9, pp. 159-165.

Horváth, Gy. (2019): Fondut a halandóságban? Biztositás és Kockázat, 3., pp. 18-33.

Human Mortality Database. University of California, Berkeley (USA), and Max Planck Institute for Demographic Research (Germany).

Available at wWw.mortality.org, letöltve 2020.06.07-én.
Jindrová, P. - Slavićek, O. (2012): Life expectancy development and prediction for selected European countries. 6-th International

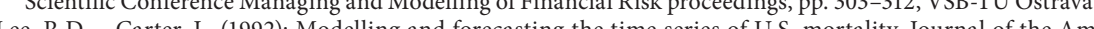
Association, 87, pp. 659-671.

Májer, I. - Kovács, E. (2011): ElettartamURL: http:///www.ksh.hu//statszemle_archive/2011/2011_07-08/2011_07-08_790.pdf, letölttve 2020.06.07-én. on Mathematical Methods in Applied Sciences (MMAS'14), Saint Petersburg State Polytechnic University, pp. 170-174.

R Development Core Team (2005): R: A language and environment for statistical computing. R Foundation for Statistical Computing Vienna ISBN 3-900051-07-0, URL. http://www R-project org Spoorenberg, T. (2007): Quality of age reporting: extension and application of the modified Whipple's index. Population, 62(4): pp. 729-741.

ás, P. (2017): Nyugdíjcélú életjáradékok élettartam-kockázata az általánosított korcsoport-időszak-kohorsz modellkeretben. Statisztikai Szemle, 95(2): pp. 139-165.
https://doi.org/10.20311/stat2017.02.hu0139 letöltve 2020.06.07-én.

Vékás, P. (2018): Változások a halandóságjavulás mintázatában Magyarországon. Biztositásés Kockázat, 5(3): pp. 34-47. URL:https:// mabisz.hu/wpcontent/uploads/2018/08/biztositas-es-kockazat-5-evf-3-szam-5-cikk.pdf, https://doi.org/10.18530/bk.2018.3.34 letölttve 2020.06.07-én

Vékás, P. (2019): Rotation of the age pattern of mortality improvements in European Union member countries. Central European Journal of Operations Research. URL: https://doi.org/10.1007/s10100-019-00617-0, letöltve 2020.06.07-en.
Villegas, A. M - Kaishev, V - Millossovich, P. (2016): StMoMo: An R Package for Stochastic Mortality Modelling

https://doi.org/10.2139/ssrn.2698729 letöltve 2020.06.07-én - 